\title{
Effect of type of solvent on the sol-Gel spin coated CZTS thin films
}

\begin{abstract}
In recent times, the kieserite material based thin film solar cells are acquiring a substantial attention. The quaternary $\mathrm{Cu}_{2} \mathrm{ZnSnS}_{4}$ (CZTS) is considered as promising next generation semiconducting material owing to requirement earth abundant and environmentally constituents, its direct band gap of 1.4-1.6eV with p-type conductivity and high absorbance coefficient $\left(10^{4} \mathrm{~cm}^{-1}\right)$. In this paper, the effect of type of solvent on the sol-gel spin coated CZTS thin film is studied. The sol-gel solution is prepared using four different environment-friendly solvents, namely, Dimethyl sulfoxide, Isopropyl alcohol, Ethylene glycol and Propylene glycol. The thin film prepared using the most cost effective spin coating technique. XRD patterns of all the prepared samples shows single phase CZTS with preferential orientation along (112) direction for kieserite structure. Morphological analysis is carried out using SEM. The morphological analysis suggested the sample prepared using propylene glycol is superior. The optical analysis is carried out using UV-Visible and it also suggested that propylene glycol is best suitable solvent as best band gap $(1.51 \mathrm{eV})$ is achieved. The solar cell is fabricated for CZTS thin film prepared using propylene glycol and $3.02 \%$ of solar cell efficiency is achieved.
\end{abstract}

Keywords: CZTS, thin film, Sol-gel spin coating, solvent
Volume I Issue 4 - 2017

Siddhant B Patel, Jignasa V Gohel

Department of Chemical Engineering, SV National Institute of Technology, India

Correspondence: Jignasa V Gohel, Department of Chemical Engineering, SV National Institute of Technology, Surat-395007, Gujarat, India, Tel (026I) 2201642, Email sjn@ched.svnit.ac.in

Received: August 21, 2017| Published: November 08, 2017
Abbreviations: DMSO, dimethyl sulfoxide; IPA, isopropyl alcohol; EG, ethylene glycol; PG, propylene glycol; FTO, fluorine doped tin oxide; XRD, X-ray diffraction; SEM, scanning electron microscope; PCE, power conversion efficiency

\section{Introduction}

Kesterite material based thin film solar cells are most favorable to replace currently available silicon based solar cell owing to low fabrication cost and good stability. At present, copper indium gallium selenide (CIGS) and cadmium telluride (CdTe) based solar cells are available in the market. However, due to the toxicity of cadmium and selenide and less availability of indium and tellurium in earth crush, the large scale production of these material based solar cell is limited. ${ }^{1}$ Hence, the new emerging kieserite quaternary material copper zinc tin sulfide (CZTS) is considered as next generation thin film absorber material. ${ }^{2}$ CZTS requires easily available in earth crush and eco-friendly materials. CZTS also possess a good direct band gap of $1.4-1.6 \mathrm{eV}$ which is close to theoretically reported optimum band gap $(1.45 \mathrm{eV})$, high absorbance coefficient $\left(10^{4} \mathrm{~cm}^{-1}\right)$ with p-type conductivity. ${ }^{3}$

Up till now, numerous CZTS thin film preparation methods are reported, such as electrode position, ${ }^{4}$ pulse laser deposition, ${ }^{5}$ thermal deposition, ${ }^{6}$ spray pyrolysis, ${ }^{7}$ sol-gel spin coating, ${ }^{8}$ etc. Among these techniques, the sol-gel spin coating is most preferred for low-cost thin film preparation. ${ }^{9}$ CZTS is a quaternary substance, hence it is very difficult to avoid the secondary phase generation. To obtain highefficiency devices, the control over secondary phase formation in CZTS is crucial. It requires good control over process parameters. In recent years, there is significant work has been carried out to improve sol-gel spin coated CZTS thin film optical and electrical properties. However still, an extensive research is required as highest reported around $7 \%$, which is lower than theoretically calculated $(32 \%) .{ }^{10}$ In our previous study, ${ }^{11}$ the CZTS thin film quality controlling parameters are listed. Selection of solvent is one of the key parameters for sol-gel spin coating. Solvent controls optical, structural as well as morphological properties of the thin film in the sol-gel spin coating. Hence, in the present study, the effect of type of solvent on the properties of CZTS thin film is studied extensively. Further, the solar cell is fabricated and efficiency is measured.

The four different solution was prepared using four different environment-friendly solvents, namely, DMSO, IPA, EG, and PG. Copper chloride $\left(\mathrm{CuCl}_{2} \cdot 2 \mathrm{H}_{2} \mathrm{O}\right)$, zinc acetate $\left(\mathrm{Zn}\left(\mathrm{O}_{2} \mathrm{CCH}_{3}\right)_{2}\left(\mathrm{H}_{2} \mathrm{O}\right)_{2}\right)$, tin chloride $\left(\mathrm{SnCl}_{2} \cdot 2 \mathrm{H}_{2} \mathrm{O}\right)$ and thiourea $\left(\mathrm{SC}\left(\mathrm{NH}_{2}\right)_{2}\right)$ were used as a source of $\mathrm{Cu}, \mathrm{Zn}, \mathrm{Sn}$, and $\mathrm{S}$, respectively. The precursors were added into DMSO and stirred for $60 \mathrm{~min}$ at $50^{\circ} \mathrm{C}$ temperature. A few drops of MEA were added as a stabilizer. A clear yellowish solution is acquired after completion of the process. The same procedure was carried out for IPA, EG, and PG and a clear yellow solution was obtained. Further, the solution was applied on the FTO glass substrate and coated at $2000 \mathrm{rpm}$. Subsequently, the film is baked at $230^{\circ} \mathrm{C}$. The coating process was repeated for 7-8 times and finally, the film is annealed under vacuum at $500^{\circ} \mathrm{C}$, to avoid toxic $\mathrm{H}_{2} \mathrm{~S}$ annealing. Four different films were prepared using different solvents based solutions.

The structural property of CZTS film is characterized by XRD using Rigaku D/Max 2200 system with $\mathrm{CuK}_{\alpha}$ radiation $\left(\mathrm{CuK}_{\alpha}=1.54 \AA\right)$. The XRD pattern suggested that all the films are single phase CZTS thin film (see Figure 1). No evidence on secondary phase is observed. All the films have exhibited (112) plane orientation which leads to the presence of frequently reported kieserite structure. ${ }^{12-15}$ The superior intensity is achieved by film prepared using PG as a solvent, which suggests the better crystalline is achieved. 


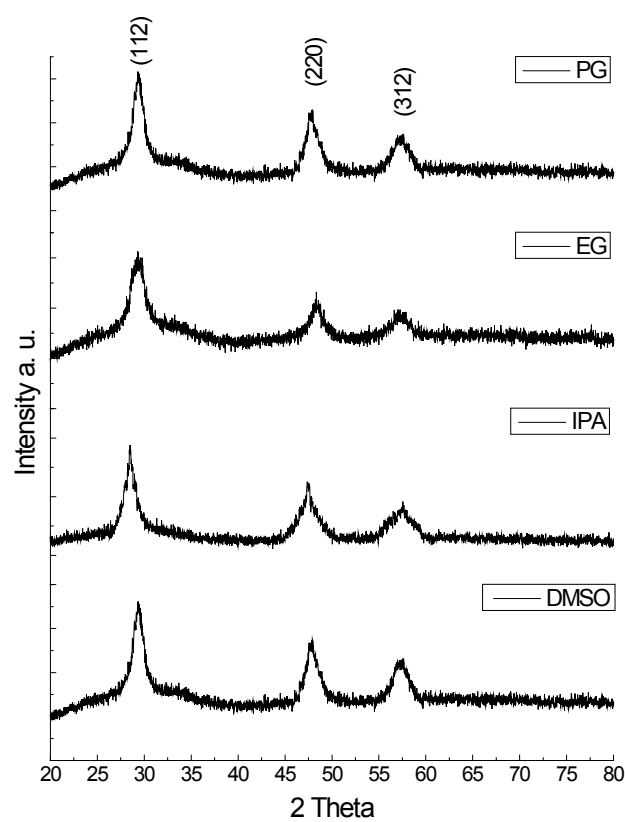

Figure I XRD pattern of thin film prepared using different solvents.

The surface morphology of CZTS thin film is studied using scanning electron microscope S3400, Hitachi International Ltd. The surface morphology is hugely affected by solvent variation. The different solvent formed different shaped and sized nano particles Figure 2(a-d). Figure 2a depicts the surface morphology of thin film prepared using DMSO as a solvent. A clearly rope shaped surface morphology with minor voids can be observed for DMSO. The thin film prepared using IPA as solvent exhibited connected nano particle as elements are connected in DNA (Figure 2b). However, some voids can be observed. The film prepared using EG as solvent shows flower shape morphology (Figure 2c). However, agglomeration of nano particles can be observed as well. It is well reported that the uniform surface morphology is essential, as agglomeration may lead to the reduction in grain boundaries., ${ }^{9}, 18$ It leads to increase in the effective diffusion length of minority carrier, which ultimately leads to poor solar cell performance. ${ }^{19}$ Ali et al. ${ }^{20}$ have reported that voids can adversely affect the electrical and optical properties of the films. Hence, both agglomeration and voids are not desired. A well dispersed, uniform and dense surface morphology is observed for the thin film prepared using PG as solvent (Figure 2d). Hence, the film prepared using PG as a solvent is considered the best.

Optical analysis of the thin film is carried out using HACH-DR $6000 / 2$ UV spectrometer. The band gap is evaluated using Tauc's plot method. Figure 3 illustrates the Tauc's plot of thin film prepared using different solvents. However, the solvent variation doesn't affect much the optical properties of thin films as all films exhibited band gap in the range of $1.5-1.6 \mathrm{eV}$, which is frequently reported. ${ }^{21-23}$ Shockley and Queisser had theoretically calculated that maximum solar cell efficiency $(33 \%)$ can be achieved at low band gap, preferably at $1.45 \mathrm{eV} .{ }^{24}$ Hence, preferably low band gap is desired for the superior solar cell performance.
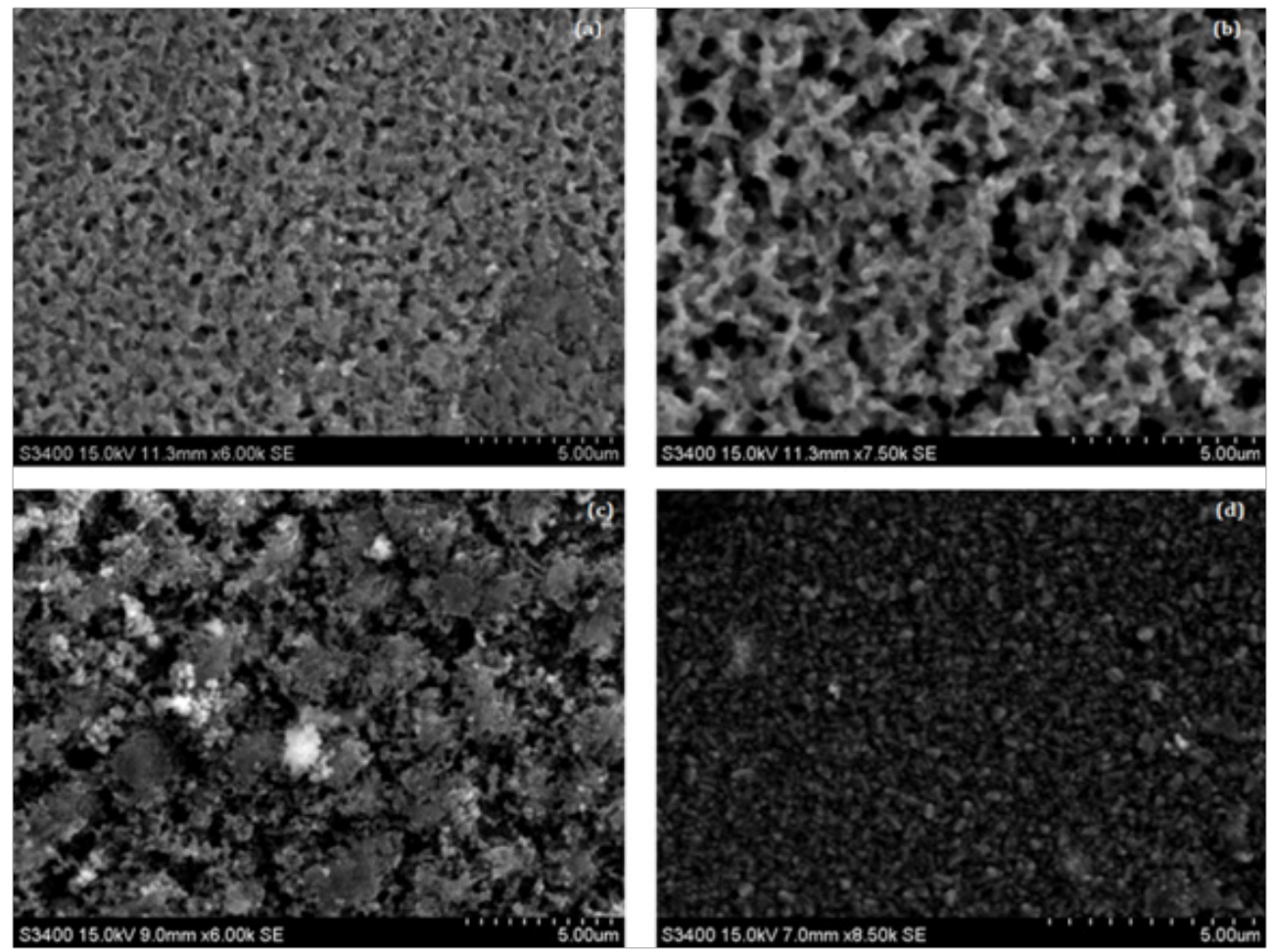

Figure 2 Surface morphology of thin film prepared by using (a) DMSO (b) IPA (c) EG and (d) PG as solvent. 


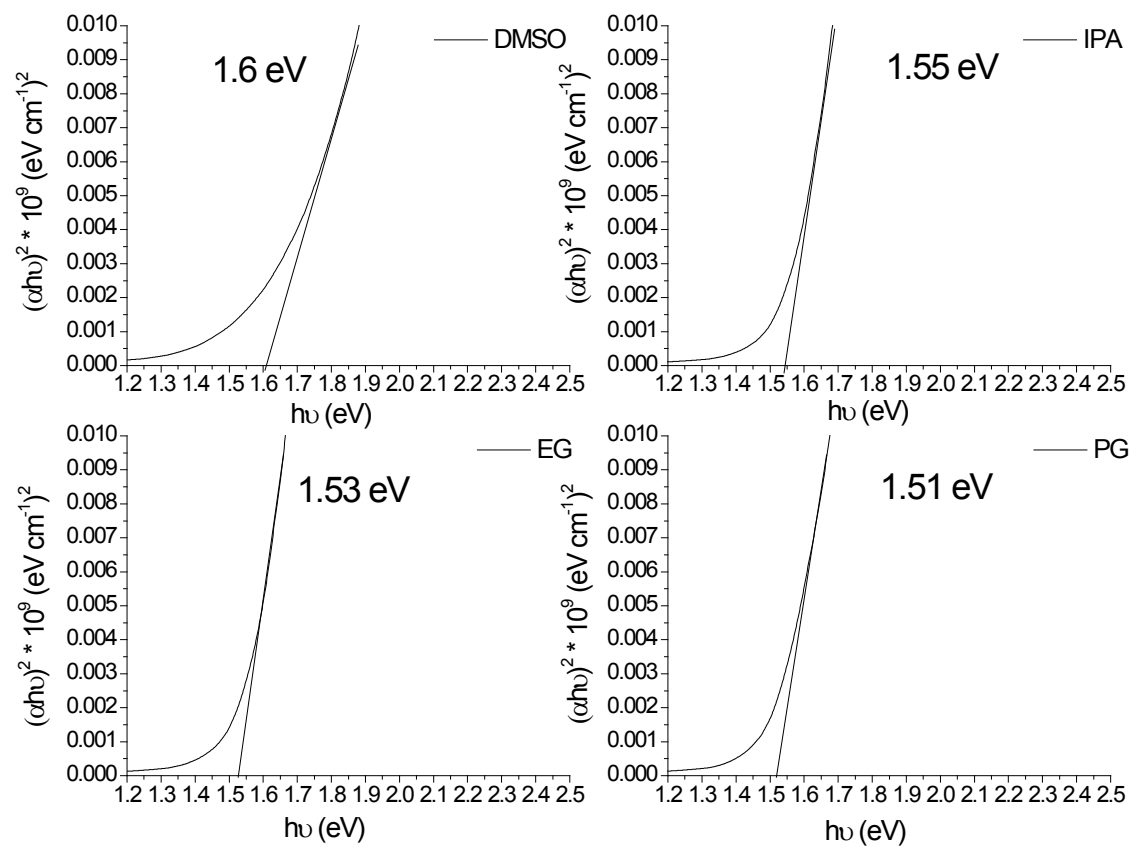

Figure 3 Tuac's $(\alpha h v)^{2}$ vs ho plot of thin film prepared using different solvents.

However, in the present study, the film preparation with another solvent could not lead to low band gap. The films prepared with DMSO IPA and EG led to high band gap of $1.6 \mathrm{eV}, 1.55 \mathrm{eV} 1.53 \mathrm{eV}$, respectively. The minimum band gap is only achieved with the film prepared with PG as a solvent; hence, it may be termed as superior film compared other films. Basically, the superior crystalline and surface morphology is achieved for the film prepared with PG. In addition, the superior crystalline and surface morphology can further lead to large grain size. And it is well reported that larger the grain size, smaller is the band gap..$^{23}$ Hence, attributed to the superior crystalline and surface morphology achieved with the film prepared by PG, the film depicted smaller and superior band gap, in the present study.
The solar cell is fabricated by the thin film prepared using PG as a solvent. The frequently reported CZTS solar cell structure is TCO/ $\mathrm{CZTS} / \mathrm{CdS} / \mathrm{ZnO} /$ Back contact. ${ }^{25-27}$ In the present study, FTO is used as TCO and CuS/FTO is used as a back contact to comply the tandem cell principle. Hence, cell structure becomes FTO/CZTS/CdS/ZnO/ $\mathrm{CuS} / \mathrm{FTO}$. The solar cell performance is measured using Keithley 2400 under AM 1.5G illumination at $1000 \mathrm{~W} / \mathrm{m}^{2}$. The solar cell has exhibited $3.02 \%$ of PCE with $15.6 \mathrm{mAcm}^{-2}$ current density $\left(\mathrm{J}_{\mathrm{SC}}\right)$, $450 \mathrm{mV}$ open circuit voltage $\left(\mathrm{V}_{\mathrm{OC}}\right)$ and $43 \%$ fill factor. Figure 4 depicts the $\mathrm{J}-\mathrm{V}$ characteristics of the solar cell.

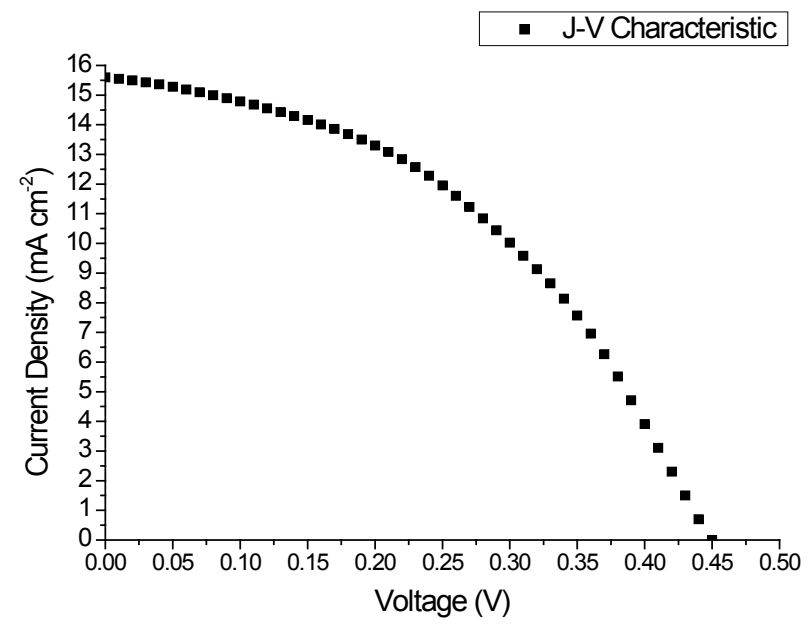

Figure $4 \mathrm{~J}-\mathrm{V}$ characteristic of solar cell prepared by thin film prepared using PG as solvent. 


\section{Conclusion}

In the present study, the effect of type of solvent on the optical and electrical properties of CZTS thin film is studied extensively. The four environ-friendly solvents, namely, DMSO, IPA, EG, and PG are used for the preparation of the sol-gel solution. The CZTS thin film is prepared successfully using spin coating technique. All four thin film exhibited kieserite structure. However, the superior intensity is achieved by film prepared using PG as a solvent. The solvent affected surface morphology of thin film extensively. Different solvent formed different shaped and size nano particles. DMSO formed rope shaped morphology with minor voids, IPA formed DNA type connected surface morphology with voids, EG formed flower shaped morphology with some agglomeration of nano particles. Uniform, well dispersed and dense morphology is achieved by film prepared using PG as a solvent. Optical properties are not affected widely by the solvent variation. However, superior band gap $(1.51 \mathrm{eV})$ is achieved by film prepared using PG as a solvent. A tandem cell is fabricated by thin film prepared using PG as a solvent and $3.02 \%$ of PCE is achieved.

\section{Acknowledgments}

The authors would like to acknowledge the sophisticated instrumentation center and Department of Chemical Engineering of S.V. National Institute of Technology, Surat, India.

\section{Conflicts of Interest}

Author Declare there is no conflict of interest.

\section{References}

1. Shi Z, Attygalle D, Jayatissa AH. Kesterite-based next generation high performance thin film solar cell: current progress and future prospects. Journal of Materials Science: Materials in Electronics. 2017;28(2):22902306.

2. Suryawanshi MP, Agawane GL, Bhosale SM, et al. CZTS based thin film solar cells: a status review. Material Technology. 2013;28(1-2):98-109.

3. Song X, Ji X, Li M, et al. A review on development prospect of CZTS based thin film solar cells. International Jornal of Photoenergy. 2014.

4. Khalil MI, Atici O, Lucotti A, et al. CZTS absorber layer for thin film solar cells from electrodeposited metallic stacked precursors $(\mathrm{Zn} / \mathrm{Cu}-\mathrm{Sn})$. Applied Surface Science. 2016;379:91-97.

5. Moholkar AV, Shinde SS, Babar AR, et al. Development of CZTS thin films solar cells by pulsed laser deposition: Influence of pulse repetition rate. Solar Energy. 2013;85(7):1354-1363.

6. Sripan C, Madhavan VE, Viswanath AK, et al. Sulfurization and annealing effects on thermally evaporated CZTS films. Materials Letters. 2017; 189:110-113.

7. Patel S, Gohel JV. Synthesis and characterization of Copper Zinc Tin Sulfide films prepared by spray pyrolysis deposition. International Conference on Sustainable Development for Energy and Environment, India. 2017.

8. Liu R, Tan M, Zhang X, et al. Impact of sol-gel precursor treatment with preheating temperature on properties of $\mathrm{Cu}_{2} \mathrm{ZnSnS}_{4}$ thin film and its photovoltaic solar cell. Journal of Alloys and Compounds. 2016;655:124129 .

9. Lanjewar M, Gohel JV. Enhanced performance of Ag-doped $\mathrm{ZnO}$ and pure $\mathrm{ZnO}$ thin films DSSCs prepared by sol-gel spin coating. Inorganic and Nano-Metal Chemistry. 2017;47(7):1090-1096.
10. Li X, Su Z, Venkataraj S, et al. 8.6\% Efficiency CZTSSe solar cell with atomic layer deposited Zn-Sn-O buffer layer. Solar Energy Materials \& Solar Cells. 2016;157:101-107.

11. Patel SB, Gohel JV. Recent developments in $\mathrm{Cu}_{2} \mathrm{ZnSnS}_{4}$ (CZTS) preparation, optimization and its application in solar cell development and photocatalytic applications. Material Research Forum. 2017.

12. Yu Y, Ge J, Prabhakar T, et al. Effects of spin speed on the properties of spin-coated $\mathrm{Cu}, \mathrm{ZnSnS}$ thin films and solar cells based on DMSO solution. Photovoltaic Specialist Conference (PVSC), 2014. p. 448-451.

13. Yeh MY, Lee CC, Wuu DS. Influences of synthesizing temperatures on the properties of $\mathrm{Cu}_{2} \mathrm{ZnSnS}_{4}$ prepared by sol-gel spin-coated deposition. Journal of Sol-Gel Science and Technology. 2009;52(1):65-68.

14. Swami SK, Kumar A, Dutta V. Deposition of kesterite $\mathrm{Cu}_{2} \mathrm{ZnSnS}_{4}$ (CZTS) thin films by spin coating technique for solar cell application. Energy Procedia. 2013;33:198-202.

15. Wang J, Zhang P, Song X,et al. $\mathrm{Cu}_{2} \mathrm{ZnSnS}_{4}$ thin films: spin coating synthesis and photo electrochemistry. RSC Advance. 2014;4(41): 21318-21324.

16. Gohel JV, Jana AK, Singh M. Highly enhanced photocurrent of novel quantum-dot-co-sensitized $\mathrm{PbS}-\mathrm{Hg} / \mathrm{CdS} / \mathrm{Cu}: \mathrm{ZnO}$ thin films for photoelectrochemical applications. Applied Physics A. 2017;123(8):1-12.

17. Kumari N, Gohel JV, Patel SR. Multi-response optimization of ZnO thin films using Grey-Taguchi technique and development of a model using ANN. Optik - International Journal for Light and Electron Optics. 2017; 144:422-435.

18. Mishra PS, Solanki JN, Murthy ZVP. $\mathrm{TiO}_{2}$ nanoparticles synthesis for application in proton exchange membranes. Crystal Research Technology. 2013;48(11):969-976.

19. Bhosale SM, Suryawanshi MP, Kim JH, et al. Influence of copper concentration on sprayed CZTS thin films deposited at high temperature. Ceramics International. 2015;41(7):8299-8304.

20. Ali N, Hussain A, Ahmed R, et al. Advances in nanostructured thin film materials for solar cell applications. Renewable \& Sustainable Energy Reviews. 2016;59:726-737.

21. Chen J, Chen Q, Ni Y, et al. The synthesis of $\mathrm{Cu}_{2} \mathrm{ZnSnS}_{4}$ nanoparticles via an open-air solution route: influences of $\mathrm{Zn}$ precursor content. Journal of Sol-Gel Science and Technology. 2015;75(1):25-30.

22. Prabeesh P, Saritha P, Selvam IP, et al. Fabrication of CZTS thin films by dip coating technique for solar cell applications. Materials Research Bulletin. 2017;86:295-301.

23. Henry J, Mohanraj K, Sivakumar G. Electrical and optical properties of CZTS thin films prepared by SILAR method. Journal of Asian Ceramic Societies. 2016;4(1):81-84.

24. Shockley W, Queisser HJ. Detailed balance limit of efficiency of p-n junction solar cells. Journal of Applied Physics. 1961;32 (3):510-519.

25. Agawane GL, Kamble AS, Vanalakar SA, et al. Fabrication of 3.01\% power conversion efficient high-quality CZTS thin film solar cells by a green and simple sol-gel technique. Materials Letters. 2015;158:58-61.

26. Tunuguntla V, Chen WC, Shih $\mathrm{PH}$, et al. A nontoxic solvent based sol-gel $\mathrm{Cu}_{2} \mathrm{ZnSnS}_{4}$ thin film for high efficiency and scalable low-cost photovoltaic cells. Journal of Material Chemistry A. 2015;3(29):15324-15330.

27. Chen G, Yuan C, Liu J, et al. Fabrication of $\mathrm{Cu}_{2} \mathrm{ZnSnS}_{4}$ thin films using oxides nanoparticles ink for solar cell. Journal of Power Sources. 2005;276:145-152. 